\title{
EFEKTIVITAS BIAYA PENGGUNAAN ANTIBIOTIK SIPROFLOKSASIN DAN SEFTRIAKSON PADA PASIEN INFEKSI SALURAN KEMIH RAWAT INAP DI RSU ANUTAPURA PALU TAHUN 2016-2017
}

\author{
Siti Atika, Ihwan, Muhamad Rinaldhi Tandah \\ Fakultas Matematika dan Ilmu Pengetahuan Alam Uniiversitas Tadulako, Palu \\ Email : atikasiti281@gmail.com
}

\begin{abstract}
Urinary tract infection is an infection that comes from bacteria and affects the top or bottom of the urinary tract. Effective treatment can be done by choosing and using appropriate antibiotics. The principle of selecting antibiotics is called cost effective. This study aims to analyze the cost-effectiveness of using ciprofloxacin and ceftriaxone antibiotics in patients with urinary tract infection. The method used is retrospectively quantitative. Data obtained from medical records, and medical payment in the form of direct medical costs of ciprofloxacin and ceftriaxone antibiotics on inpatient with urinary tract infection at General Hospital Anutapura in the period of 2016-2017. The results showed the cost-effectiveness of antibiotics ceftriaxone is more cost effective than ciprofloxacin antibiotics with an ACER value of Rp12.249,5 and ICER value of Rp2.336,5. Based on the cost-effectiveness of antibiotics the results of chi-square test obtained $p$ value $=0.157$, it is concluded that there is no significant difference between ciprofloxacin and ceftriaxone.
\end{abstract}

Key Words: Cost Effectiveness, Urinary Tract Infection, Ciprofloxacin, Ceftriaxone.

\section{PENDAHULUAN}

Infeksi saluran kemih (ISK) merupakan infeksi akut atau kronik yang berasal dari bakteri dan akan mempengaruhi bagian atas atau bawah saluran kemih. ${ }^{1}$ Di Amerika Serikat tahun 2007 diperkirakan 10,5 juta kasus di rumah sakit diakibatkan infeksi saluran kemih $(0,9 \%$ dari kunjungan rawat jalan) dan 2-3 juta pasien gawat darurat. Biaya untuk infeksi yaitu biaya perawatan dan waktu yang hilang untuk pekerjaan diakibatkan sakit diperkirakan $\$ 3,5$ juta miliar pertahun. ${ }^{2}$ Menurut data Departemen Kesehatan RI tahun 2014 menunjukkan bahwa penderita infeksi saluran kemih mencapai 90-100 kasus per 100.000 penduduk pertahun dan sekitar 180.000 kasus baru pertahun. ${ }^{3}$

Menurut penelitian Syafada tahun 2013 bahwa hasil kultur kuman diperoleh golongan kuman terbanyak yang menyebabkan ISK adalah kuman gram negatif (62\%), kemudian kuman gram positif (28\%), dan yang terakhir 
Analisis efektivitas biaya penggunaan antibiotik Siprofloksasin dan Seftriakson pada pasien Infeksi Saluran Kemih Rawat Inap Di RSU Anutapura Palu tahun 2016-2017

fungi (10 \%), sedangkan kuman penyebab ISK terbanyak adalah kuman Escherichia coli, kemudian kuman Pseudomonas aeruginosa, kuman Staphylococcus coagulase negatif, dan kuman Klebsiella pneumonia. ${ }^{5}$ Hal yang perlu dilakukan adalah dengan menggunakan terapi antibiotik yang tepat untuk setiap pasien sehingga dapat menunjang kesembuhan pasien tersebut. Siprofloksasin merupakan terapi antimikroba yang paling sering digunakan pada terapi ISK. Siprofloksasin memiliki sifat bakterisid, yang berguna terutama dalam mengobati infeksi yang disebabkan oleh $E$. coli dan bakteri gram negatif lainnya. Selain itu, digunakan juga antimikroba yang memiliki spektrum yang luas yaitu seftriakson.

Seftriakson memiliki sifat bakterisid yang kuat pada ISK.

Cara yang komprehensif untuk menentukan pengaruh ekonomi dari alternatif terapi obat atau intervensi kesehatan lain yaitu dengan analisis farmakoekonomi yang berupa cost effectiveness analysis (CEA) atau analisis efektivitas biaya. ${ }^{4}$ CEA adalah suatu metode evaluasi ekonomi yang digunakan untuk membantu pengambil keputusan klinik dalam memilih pilihan terapi yang paling cost-effective.
Beberapa penelitian menyebutkan bahwa pembiayaan biaya medis langsung untuk ISK di instalasi rawat inap RSU Anutapura Palu 2016 berdasarkan semua kelas perawatan bahwa penggunaan antibiotik siprofloksasin sebesar Rp.808.304 dengan lama rawat inap selama 1-3 hari dan untuk seftriakson sebesar Rp.1.945.938 dengan lama rawat inap selama 2-5 hari. Pada penelitian tersebut dilakukan analisis biaya penggunaan antibiotik pasien ISK tetapi belum diterapkan perbandingan efektivitas biaya penggunaan antibiotik. Oleh karena itu, perlu diteliti lebih lanjut mengenai besarnya biaya pasien ISK yang menjalani rawat inap di RSU Anutapura Palu menggunakan metode cost effectiveness analysis. Diharapkan dengan adanya penelitian ini dapat menjadi pertimbangan bagi tenaga kesehatan dalam pemberian obat antibiotik untuk mencapai kesembuhan dan menghemat pengeluaran biaya pasien tersebut.

\section{METODE PENELITIAN}

Penelitian ini merupakan penelitian kuantitatif, dengan pendekatan secara retrospektif data diperoleh dari rekam medik, dan bukti pembayaran pengobatan berupa biaya medis langsung dari penggunaan antibiotik siprofloksasin 
Analisis efektivitas biaya penggunaan antibiotik Siprofloksasin dan Seftriakson pada pasien Infeksi Saluran Kemih Rawat Inap Di RSU Anutapura Palu tahun 2016-2017

dan seftriakson pasien infeksi saluran kemih rawat inap di RSU Anutapura tahun 2016-2017. Data yang diperoleh dihitung dengan menggunakan CEA (Cost Effectiveness Analysis) berdasarkan nilai ACER (Average Cost-Effectiveness Ratio) dan ICER (Incremental Cost-Effectiveness Ratio) untuk efektivitas biaya (cost effective) dan untuk efektivitas pengobatan dinilai berdasarkan outcome klinik yaitu sedimen leukosit dalam urin dan lama pemberian antibiotik.

Populasi pada penelitian ini adalah semua pasien infeksi saluran kemih di RSU Anutapura Palu. Sampel pada penelitian adalah semua pasien infeksi saluran kemih di RSU Anutapura Palu tahun 2016-2017 yang memenuhi kriteria inklusi dan eksklusi. Kriteria inklusi : pasien yang didiagnosa infeksi saluran kemih tanpa penyakit penyerta, pasien yang menjalani rawat inap di kelas 3 RSU Anutapura pasien yang mendapatkan terapi dengan antibiotik siprofloksasin atau seftriakson, dan pasien yang mendapatkan tes urinalisis sebelum dan sesudah terapi antibiotik siprofloksasin dan seftriakson. Kriteria eksklusi : pasien dengan data rekam medis yang tidak lengkap dan pulang paksa.
Data yang dikumpulkan merupakan data sekunder yang dilakukan dengan cara mencatat isi rekam medik pasien meliputi : identitas pasien (nomor rekam medik, jenis kelamin, umur, pekerjaan, dan jenis antibiotik yang digunakan), Karakteristik klinik (lama rawat inap, lama pemberian antibiotik, cara keluar, manifestasi klinik, diagnosa), profil penggunaan antibiotik siprofloksasin dan seftriakson, tes urinalisis berupa sedimen leukosit dalam urin, dan biaya medis langsung berupa biaya tindakan medis, biaya kamar inap, biaya antibiotik, biaya obat penunjang, biaya alat kesehatan dan biaya laboratorium.

Analisis data yang dilakukan secara deksriptif dan kuantitatif. Analisis deskriptif dilakukan untuk menjelaskan atau memberikan gambaran karakteristik setiap variabel penelitian meliputi : karakteristik subyek penelitian meliputi : jenis kelamin, umur, pekerjaan, jenis penggunaan antibiotik, karakteristik klinik meliputi manifestasi klinik dan efektivitas pengobatan meliputi : lama pemberian antibiotik, dan sedimen leukosit dalam urin diuji dengan statistik nonparametrik Chi-Square Test. Analisis kuantitatif yang dilakukan dengan menghitung biaya medis langsung meliputi : biaya 
Analisis efektivitas biaya penggunaan antibiotik Siprofloksasin dan Seftriakson pada pasien Infeksi Saluran Kemih Rawat Inap Di RSU Anutapura Palu tahun 2016-2017

tindakan medis, biaya kamar inap, biaya antibiotik, biaya obat penunjang, biaya alat kesehatan dan biaya laboratorium. Data yang telah diolah dihitung efektivitas biaya menggunakan rumus ACER (Average Cost-Effectiveness Ratio) dan ICER (Incremental Cost-Effectiveness Ratio).

HASIL

PENELITIAN

DAN

\section{PEMBAHASAN}

Total pasien ISK tanpa penyakit penyerta di RSU Anutapura Palu tahun 2016-2017 sebanyak 296 pasien, jumlah pasien yang memenuhi kriteria inklusi dan ekslusi untuk dilakukan analisis lebih lanjut adalah 33 pasien. Pasien yang tidak memenuhi kriteria inklusi dan esklusi berjumlah 263 pasien. Hal ini disebabkan karena tidak memiliki data pemeriksaan yang lengkap dan penggunaan terapi yang tidak sesuai berupa penggunaan antibiotik lain.

\section{Karakteristik Demografi}

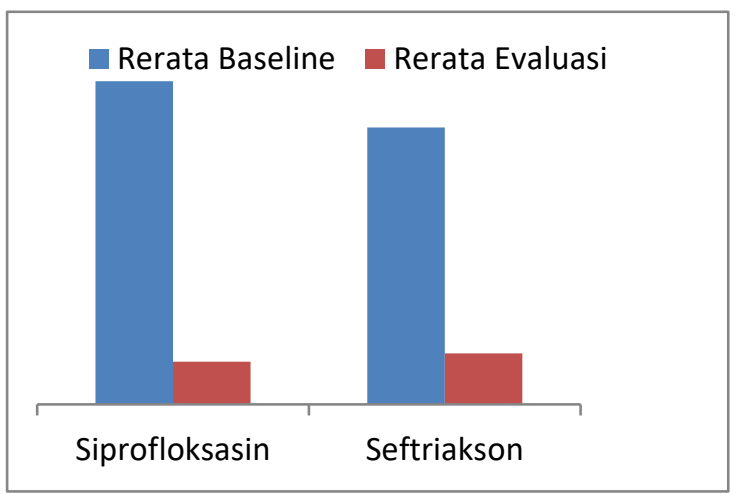

Jenis kelamin dan usia pasien ISK tertinggi pada perempuan 22 pasien dengan rentang usia 36-65 tahun $(40,90 \%)$, dan 16-35 tahun $(40,90 \%)$, hal ini sesuai dengan literatur dari Brain.,et al (2013) yang menyatakan bahwa perempuan lebih banyak terkena ISK dibanding laki-laki dan berdasarkan penelitian sebelumnya ${ }^{1,5}$ pasien ISK lebih banyak menyerang perempuan yaitu 41 pasien $(51,90 \%)$ dan golongan umur terbanyak adalah 25-65 tahun yaitu 39 pasien (49,37\%). Hal ini disebabkan karena perbedaan anatomi dan fisiologis, uretra perempuan lebih pendek sehingga bakteri kontaminan lebih mudah masuk ke kandung kemih. Faktor resiko lain yang dapat menyebabkan infeksi saluran kemih pada perempuan adalah kecenderungan dalam menahan urine, serta iritasi kulit lubang uretra pada wanita sewaktu berhubungan intim. ${ }^{6}$

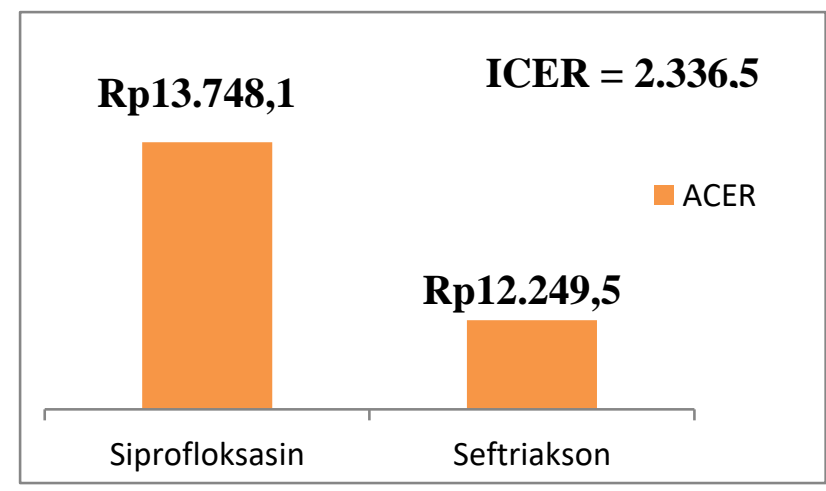

Gambar 1. (A) Rata-rata sedimen leukosit dalam urin pasien ISK; (B) Hasil Analisa ACER dan ICER terhadap biaya penggunaan antibiotik siprofloksasin dan seftriakson per perawatan pada pasien ISK. 


\section{Efektivitas Pengobatan}

\section{Sedimen Leukosit Urin}

Sedimen leukosit dalam urin merupakan adanya leukosit dalam urin, dimana pada umumnya sel darah putih seharusnya tidak ada pada urin normal dengan kisaran nilai normal 0 5/lpb. Leukosit dalam urin apabila $>5 /$ lpb maka disebut piuria atau leukosituria, maka dapat menunjukkan adanya infeksi pada saluran kemih. ${ }^{1}$ Berdasarkan gambar 1 terlihat bahwa kedua antibiotik tersebut dapat menurunkan sedimen leukosit urin. Siprofloksasin merupakan antibiotik kedua yang bersifat bakterisidal dan concentration dependent adalah rejimen dosis yang ideal untuk antibiotik ini dengan memaksimalkan kadar, semakin tinggi kadar maka semakin ekstensif dalam membunuh bakteri. ${ }^{7}$ Seftriakson merupakan antibiotik golongan sepalosporin generasi ketiga bersifat bakterisidal dan time dependent adalah rejimen dosis yang ideal untuk antibiotik ini dengan memaksimalkan durasi paparan, efikasi dilihat dengan waktu (t) diatas KHM (Kadar Hambat Minimum). Kedua antibiotik ini memiliki mekanisme kerja yang berbeda siprofloksasin bekerja dengan menghambat pembentukan DNA bakteri dengan menghambat topoisomerase II (DNA girase) dan topoisomerase IV bakteri sedangkan seftriakson menghambat pertumbuhan bakteri dengan menganggu reaksi transpeptidasi sintesis dinding sel bakteri.

\section{Lama Pemberian Antibiotik}

Tabel 1. Distribusi lama pemberian antbiotik siprofloksasin dan seftriakson pada pasien ISK

\begin{tabular}{cccc}
\hline Terapi & \multicolumn{2}{c}{ Lama Pemberian } & $\boldsymbol{p}$ \\
\hline \multirow{2}{*}{ Siprofloksasin } & $2-3$ hari & $4-5$ hari & \\
& 12 pasien & 5 pasien & 0.157 \\
\cline { 1 - 2 } Seftriakson & 14 pasien & 2 pasien & \\
\hline
\end{tabular}

Berdasarkan Permenkes, 2015

8 lama pemberian antibiotik empirik diberikan jangka waktu 48-72 jam (2-3 hari). Selanjutnya perlu dilakukan evaluasi berdasarkan data mikrobiologis dan kondisi klinis pasien serta data penunjang lainnya. Terapi antibiotik empirik adalah penggunaan 
Analisis efektivitas biaya penggunaan antibiotik Siprofloksasin dan Seftriakson pada pasien Infeksi Saluran Kemih Rawat Inap Di RSU Anutapura Palu tahun 2016-2017

antibiotik pada kasus infeksi atau diduga infeksi yang belum diketahui jenis bakteri penyebab dan pola kepekaannya. Berdasarkan tabel 1 menunjukkan bahwa pasien yang menggunakan antibiotik siprofloksasin yang sesuai dengan lama pemberian antibiotik empirik sebanyak 12 pasien dan untuk antibiotik seftriakson 14 pasien. Berdasarkan hasil uji statistik Chi-Square Test yang diperoleh nilai $p$ $=0.157$, karena nilai $p>0.05$ maka dapat disimpulkan bahwa tidak ada perbedaan yang signifikan bedasarkan lama pemberian antibiotik antara siprofloksasin dan seftriakson.

\section{Total Biaya Medis Langsung}

Total biaya medis langsung adalah biaya keseluruhan yang digunakan pasien sejak mulai masuk rumah sakit hingga keluar dari rumah sakit. Biaya-biaya tersebut meliputi biaya kamar inap, biaya tindakan medis, biaya antibiotik, biaya obat penunjang, biaya alat kesehatan, dan biaya laboratorium. Hasil penelitian ini menunjukkan komponen biaya terbesar pasien ISK di RSU Anutapura adalah biaya kamar inap dan biaya laboratorium sedangkan biaya terkecil adalah biaya antibiotik. Hal ini tidak sesuai dengan Yuni, 2013 ${ }^{9}$ yang menyatakan bahwa biaya antibiotik dapat memakan porsi sebesar $80,82 \%$ dari total biaya obat pasien selama menjalani rawat inap di rumah sakit. Rata-rata total biaya medis langsung yang menggunakan antibiotik siprofloksasin sebesar Rp970.339 sedangkan untuk antibiotik seftriakson sebesar Rp995.270. Pada hasil penelitian terlihat bahwa total biaya medis langsung antibiotik seftriakson lebih tinggi daripada antibiotik siprofloksasin karena sediaan injeksi lebih mahal dibandingkan sediaan tablet.

\section{Analisis Efektivitas Biaya}

Analisis efektivitas biaya dilakukan dengan menggunakan rumus ACER (Average Cost Effectiveness Ratio) dan ICER (Incremental Cost Effectiveness Ratio). Berdasarkan gambar menunjukkan bahwa nilai ACER dari antibiotik seftriakson dengan \% outcome klinik $81,25 \%$ diperoleh biaya sebesar Rp12.249,5 sedangkan untuk antibiotik siprofloksasin \% outcome klinik $70,58 \%$ diperoleh biaya sebesar Rp13.748,1. Pada hasil penelitian ini terlihat bahwa antibiotik seftriakson diperoleh nilai ACER lebih kecil dibandingkan dengan antibiotik siprofloksasin. Hal ini menunjukkan bahwa antibiotik seftriakson lebih cost effective atau memiliki biaya paling efektif dibandingkan dengan terapi 
Analisis efektivitas biaya penggunaan antibiotik Siprofloksasin dan Seftriakson pada pasien Infeksi Saluran Kemih Rawat Inap Di RSU Anutapura Palu tahun 2016-2017

antibiotik siprofloksasin. Hasil nilai ICER pada penelitian ini sebesar Rp2.336,5. Berdasarkan nilai ICER tersebut terlihat bahwa antibiotik siprofloksasin memerlukan biaya sebesar Rp2.336,5 untuk memperoleh satu outcome dari antibiotik seftriakson.

\section{KESIMPULAN}

Efektivitas pengobatan antara antibiotik siprofloksasin dan antibiotik seftriakson tidak ada perbedaan yang signifikan dengan diperoleh nilai $p=$ 0.157. Efektivitas biaya antara antibiotik siprofloksasin dan antibiotik seftriakson adalah antibiotik seftriakson lebih cost effective daripada antibiotik siprofloksasin dengan nilai ACER sebesar Rp12.249,5 dan nilai ICER sebesar Rp2.336,5.

\section{DAFTAR PUSTAKA}

1. Brian, et al. Koda-Kimble \& Young's Applied Therapeutics: The Clinical Use of Drugs. Philadephia USA : Lippincott Williams \& Wilkins, 2013 ; https://doi.org/10.1007/s13398-0140173-7.2.

2. Schappert SM, Rechtsteiner EA.
Ambulatory Medical Care Utilization Estimates for 2007. Vital Health Stat. 2011;13:1-38.

3. Departemen Kesehatan Republik Indonesia. Profil Kesehatan Indonesia. Departemen Kesehatan Republik Indonesia. (Vol. 51) ; 2014 https://doi.org/10.1037/00223514.51.6.1173.

4. Andayani TM. Farmakoekonomi Prinsip dan Metodologi. Yogjakarta: Bursa IImu; 2013.

5. Syafada F. Pola Kuman dan Sensitivitas Antimikroba pada Infeksi Saluran Kemih, Fakultas Farmasi, Universitas Sanata Dharma, Yogyakarta. Jurnal Farmasi Sains Dan Komunitas. 2013;10(1):9-13.

6. Corwin JE. Handbook of Pathophysiology $3^{\text {rd }}$ Edition. Philadephia USA: Lippincott Williams \& Wilkins,2009.

7. Peraturan Menteri Kesehatan Republik Indonesia. Pedoman Penggunaan Antibiotik,2011.

8. Peraturan Menteri Kesehatan Republik Indonesia. Pedoman Pengendalian Resistensi Antimikroba di Rumah Sakit, 2015.

9. Yuni H. Analisis Biaya Penggunaan Antibiotik Pada Pasien Rawat Inap Askes dengan Infeksi Saluran Kemih di RSUD Moewardi Surakarta Tahun 2011,2013. 